\title{
A COMPARATIVE PHYTOCHEMICAL AND PHARMACOLOGICAL ANALYSIS OF THE EXTRACTS FROM LEAVES OF THE UKRAINIAN FLORA SHRUBS
}

\author{
N.A.Blyznyuk, Yu.S.Prokopenko, V.A.Georgiyants, V.V.Tsyvunin \\ National University of Pharmacy \\ Key words: phytochemical analysis; pharmacological analysis; Ukrainian flora; shrubs; extract
}

In the Ukrainian flora such plants as Forsythia europaea Deg. et Bald, Jasminum officinale L., Berberis thunbergii DC, Weigela hybrida Jaeg., Ligustrum vulgare L., and Corylus avellana L. hold a special place among shrubs. The aim of our research was to analyse the relationship between the chemical composition and the anticonvulsant activity of the extracts from leaves of the given shrubs. The highest content of flavonoids has been determined in aqueous extracts of Forsythia europaea (2.83\%) and Corylus avellana (1.95\%) leaves comparing to other extracts. The highest amount of polyphenols has been determined in Corylus avellana ethanol (96\%) extract (1.31\%) and Jasminum officinale ethanol (50\%) extract (1.30\%). The dry aqueous extract of Corylus avellana leaves has shown the most pronounced anticonvulsant activity. Dry extracts of Berberis thunbergii leaves, Weigela hybrida leaves, and Ligustrum vulgare leaves have not revealed a significant anticonvulsant activity. According to the strength of the effect the dry aqueous extract of Corylus avellana can be a promising substance for creating an original herbal remedy with anticonvulsant properties.

Garden plants, both ornamental and edible, are one of the largest groups of plants [13]. They are widely used in horticulture both for esthetic territory design and for protection from noise and dust, as well as for agricultural households.

In the Ukrainian flora such plants as Forsythia europaea Deg. et Bald, Jasminum officinale L., Berberis thunbergii DC, Weigela hybrida Jaeg., Ligustrum vulgare L., and Corylus avellana $L$. hold a special place among shrubs, mostly due to their unintelligibility and effective appearance $[8,9]$. Therefore, shrubs widespread in Ukraine are promising objects for scientific research since different types of phytochemical and pharmacological analysis will contribute to their future demand in pharmaceutical manufacturing.

Previously, different studies, particularly by scientists of the National University of Pharmacy, devoted to the phytochemical and pharmacological research of the Ukrainian flora shrubs were carried out. For instance, the membrane stabilizing, anti-inflammatory, anticoagulant, anti-ulcer, and strengthening blood vessel activities of Corylus avellana $L$. extracts were determined $[3,7]$. The results of studying Ligustrum vulgare L. have shown the presence of different groups of compounds, as well as a pronounced anti-inflammatory and antimicrobial activity of the tincture from Ligustrum vulgare L. leaves [4].

While analysing publications devoted to the anticonvulsant activity of herbs some results concerning the study of the mechanisms of action for extracts from leaves, roots or buds of different either ornamental or edible shrubs, e. g. Forsythia europaea Deg. et Bald, Jasminum grandiflorum hydroalcoholic extract, Berberis integerrima L. (root), Corylus avellana L. (buds), etc., were found $[10,11,12,14,16,17]$. Earlier, the chemical com- position of leaves from the Ukrainian flora shrubs was analysed by the methods of absorption spectroscopy [1]. Nevertheless, during the analysis of the anticonvulsant activity of extracts of the plants mentioned the study of their chemical composition became relevant. Therefore, the aim of the present study was to analyse the relationship between the chemical composition of extracts from leaves of the Ukrainian flora shrubs and their anticonvulsant activity.

\section{Materials and Methods}

Reagents from Sigma-Aldrich (USA) and Merck (Germany) were used and prepared according to the requirements of the State Pharmacopoeia of Ukraine and European Pharmacopoeia.

Pentylenetetrazole was purchased from Sigma-Aldrich (USA).

Sodium Valproate was used in the form of syrup, $57.64 \mathrm{mg} / 1 \mathrm{ml}$ (trade name Depakine, Sanofi-Aventis, France).

Leaves of Forsythia europaea Deg. et Bald, Jasminum officinale L., Berberis thunbergii DC, Weigela hybrida Jaeg., Ligustrum vulgare L., and Corylus avella$n a L$. were gathered during the flowering season (in full bloom) in Ukraine. The herbal material was cleaned and dried. After complete drying, the dry herbs were kept at room temperature. Then, herb samples were powdered and used for further research.

The extracts were prepared as follows. Place $100 \mathrm{~g}$ of the air-dried and powdered leaves into a percolator, and allow extraction to run using water, or $50 \%$ ethanol, or $95 \%$ ethanol as a solvent in the ratio of 1 to 20 at $80^{\circ} \mathrm{C}$ for $2 \mathrm{~h}$. Then, filter the extracts and concentrate it in a vacuum-evaporation apparatus at $50-60^{\circ} \mathrm{C}$ and at $80-87 \mathrm{kPa}$ to a thick consistency. Finally, dry each extract under 


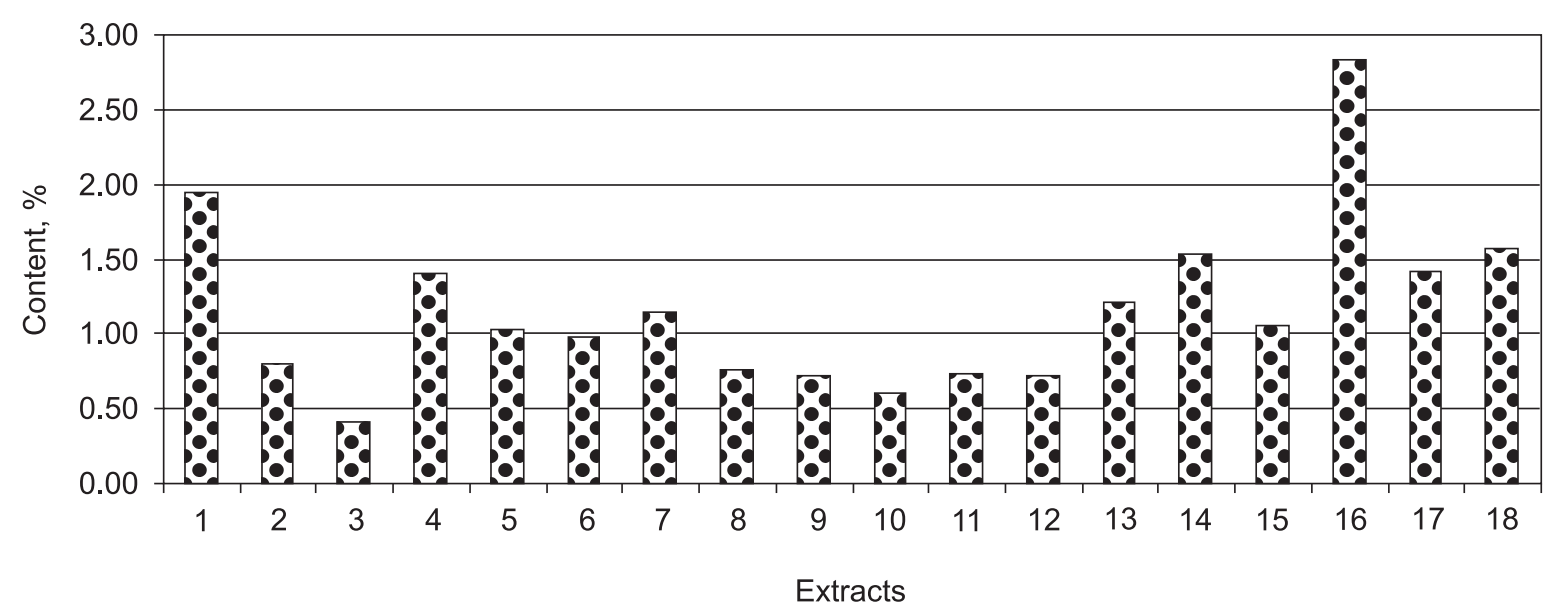
1 - C. avellana aqeous extract
2 - C. avellana ethanol (50\%) extract
3 - C. avellana ethanol (96\%) extract
4 - B. thunbergii aqeous extract
5 - B. thunbergii ethanol $(50 \%)$ extract
6 - B. thunbergii ethanol (96\%) extract
7 - L. vulgare aqeous extract
8 - L. vulgare ethanol (50\%) extract
9 - L. vulgare ethanol (96\%) extract

\begin{abstract}
10 - W. hybrida aqeous extract
11 - W. hybrida ethanol (50\%) extract

12 - W. hybrida ethanol (96\%) extract

13 - J. officinale aqeous extract

14 - J. officinale ethanol (50\%) extract

15 - J. officinale ethanol (96\%) extract

16 - F. europaea aqeous extract

17 - F. europaea ethanol (50\%) extract

18 - F. europaea ethanol (96\%) extract
\end{abstract}

Fig. 1. The content of flavonoids in the extracts analysed.

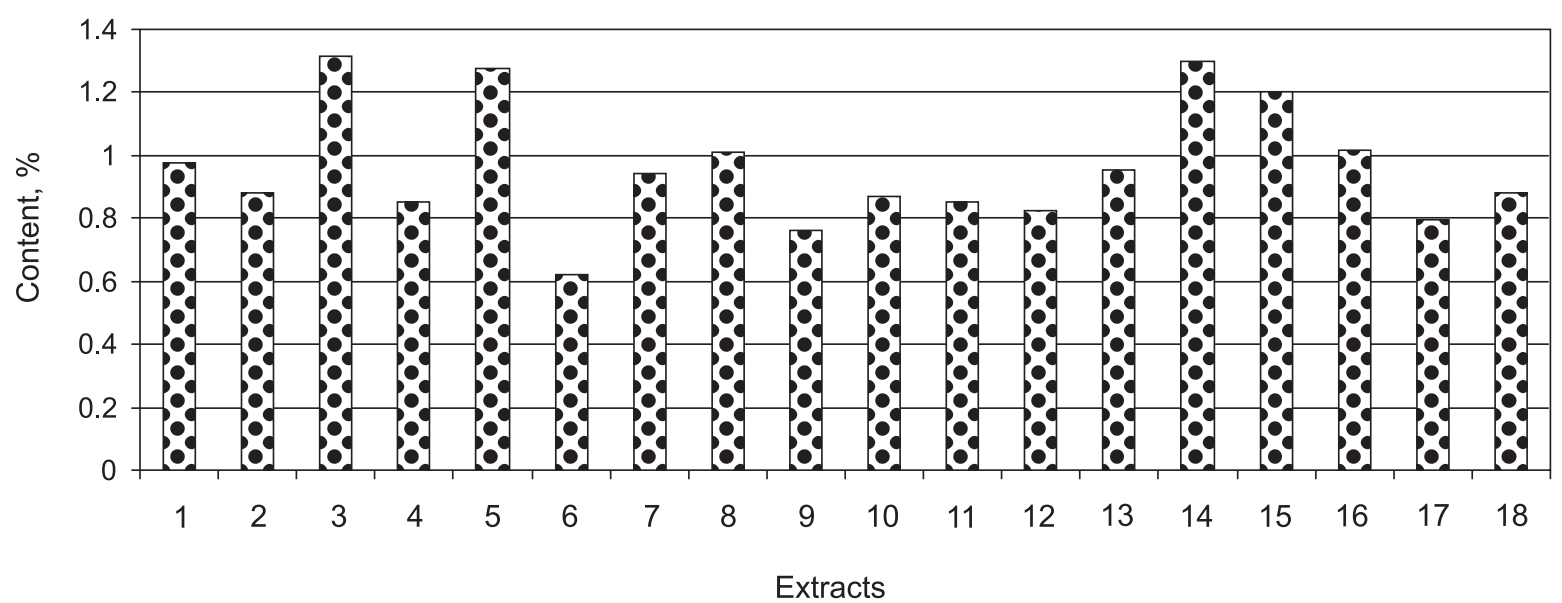

1 - C. avellana aqeous extract

2 - C. avellana ethanol (50\%) extract

3 - C. avellana ethanol ( $96 \%$ ) extract

4 - B. thunbergii aqeous extract

5 - B. thunbergii ethanol (50\%) extract

6 - B. thunbergii ethanol (96\%) extract

7 - L. vulgare aqeous extract

8 - L. vulgare ethanol (50\%) extract

9 - L. vulgare ethanol (96\%) extract
10 - W. hybrida aqeous extract

11 - W. hybrida ethanol (50\%) extract

12 - W. hybrida ethanol (96\%) extract

13 - J. officinale aqeous extract

14 - J. officinale ethanol (50\%) extract

15 - J. officinale ethanol (96\%) extract

16 - F. europaea aqeous extract

17 - F. europaea ethanol (50\%) extract

18 - F. europaea ethanol (96\%) extract

Fig. 2. The content of polyphenols in the extracts analysed. 
vacuum in the desiccators to yield a dry extract with a residual moisture content of $5 \%$.

The assay for flavonoids was carried out according to the method developed $[1,2]$. Flavonoid standard solutions of $100 \mu \mathrm{M}$ were used.

The assay for polyphenols was carried out by the method of absorption spectrometry after adding the phosphorus molybdenum-tungsten reagent [2]. The reference solution of pyrogallol was used.

Adult male random-bred albino mice weighing 18-25 g were received from the vivarium of the Central Research Laboratory at the NUPh (Kharkiv, Ukraine). The animals were treated in accordance with Directive 2010/ 63/EU of the European Parliament and of the Council of September 22, 2010, on protection of animals used for scientific purposes. The animals were randomly divided into groups of 6-8 mice.

All the experimental protocols were approved by the Committee of Bioethics of the National University of Pharmacy.

All tested samples were dissolved (or suspended) in distilled water and administered into the stomach in the empiric dose of $100 \mathrm{mg} / \mathrm{kg}$ for 2 days [6]. The reference drug Sodium Valproate was introduced intragastrically in the dose of $300 \mathrm{mg} / \mathrm{kg}$ in a similar mode [5]. The control group was treated with distilled water. The seizure agent pentylenetetrazole was given subcutaneously $(80 \mathrm{mg} / \mathrm{kg})$ on the second day for $30 \mathrm{~min}$ after introduction of herbal samples. After that the animals were observed for $1 \mathrm{~h}$ [6].

The anticonvulsant activity was assessed using the following indicators: the latency period, the number of clonic-tonic convulsions per 1 mouse, $\%$ of mice with clonic and tonic convulsions, severity of seizures, duration of the convulsive period, the time of death, lethality.

The statistical analysis was carried out using the STATISTICA 8.0 software package. Differences between experimental groups were analysed using the Mann-Whitney $\mathrm{U}$ test and the Fisher angular transformation. The level of statistical significance was considered as $\mathrm{p}<0.05$.

\section{Results and Discussion}

The content of flavonoids and polyphenols in dry extracts from leaves of the Ukrainian flora shrubs was studied and recalculated. The results are summarized in Fig. 1 and in Fig. 2, respectively.

As shown in Fig. 1, the highest content of flavonoids was determined in aqueous extracts, in particular, in dry extracts of Forsythia europaea (2.83\%) and Corylus avellana (1.95\%). The lowest content of flavonoids was determined in the dry ethanol (96\%) extract from Corylus avellana leaves $(0.41 \%)$.
In general, the results presented in Fig. 2 show rather high amount of polyphenols in the extracts analysed. Thus, the highest amount of this group of compounds was determined in ethanol $(96 \%)$ extract $(1.31 \%)$ of Corylus avellana, ethanol (50\%) extract (1.274\%) of Berberis thunbergii, and ethanol (50\%) extract $(1.30 \%)$ of Jasminum officinale. The lowest content of polyphenols was determined in the dry ethanol (96\%) extract from Berberis thunbergii leaves $(0.623 \%)$ compared to the rest of the extracts analysed.

In mice subjected to Pentylenetetrazole-induced seizures [15] the dry aqueous extract of Corylus avellana leaves, as well as the reference drug Sodium Valproate, showed the most pronounced anticonvulsant activity, resulting in a significant increase in the latency period of the first seizure occurrence, reducing lethality and duration of the convulsive period in the group. Both dry ethanol (50\%) and ethanol (96\%) extracts from Corylus avellana leaves did not practically differ from each other in their anticonvulsant activity. In general, the anticonvulsant effect of Corylus avellana extracts increased with the ethanol concentration decrease.

Dry extracts of Berberis thunbergii leaves, Weigela hybrida leaves, and Ligustrum vulgare leaves did not show a significant anticonvulsant activity: duration of the convulsive period and severity of seizures increased, as well as high lethality levels were observed in the groups compared to the control animals.

Therefore, the dry aqueous extract of Corylus avellana leaves has shown high anticonvulsant properties, which probably depend on the synergism of the effect of biologically active compounds. According to the strength of the effect the dry aqueous extract of Corylus avellana can be a promising substance for creating an original herbal remedy with anticonvulsant properties.

\section{Conclusions}

The phytochemical analysis of dry extracts from the Ukrainian flora shrubs leaves has been carried out, and their anticonvulsant properties have been studied. The results have shown a high amount of polyphenols in the extracts analysed. The highest content of flavonoids has been determined in aqueous extracts, in particular, in Forsythia europaea $(2.83 \%)$ and Corylus avellana (1.95\%) dry extracts.

The dry aqueous extract of Corylus avellana leaves has shown high anticonvulsant properties compared to the other extracts analysed. At the same time, dry extracts of Berberis thunbergii leaves, Weigela hybrida leaves, and Ligustrum vulgare leaves have not revealed a significant anticonvulsant activity.

\section{REFERENCES}

1. Близнюк Н.А., Прокопенко Ю.С., Георгіяни В.А. // Зб. наук. праць співроб. НМАПО ім. П.Л.Шупика. 2015. - Bun. 24, №4. - C. 321-325.

2. Державна фармакопея Украйни / Державне підприємство «Науково-експертний фармакопейний центр». Доп. 4. - 1-е вид. - Х.: РІРЕГ, 2011. - 538 c.

3. Пат. на кор. модель 77795 (2006) Україна, МПК (2006) А 61 K 36/185, А 61 P 1/04, А 61 P 29/00, А 61 P 39/00. Спосіб отримання комплексу біологічно активних речовин з противиразковою, протизапальною та мембраностабілізуючою дією / О.П.Хворост. - Заявл.: 22.11.2004. Опубл.: 15.01.2007. - Бюл. №1. 
4. Пат. на кор. модель 94496 (2014) Україна, МПК А 61 К 36/83. Лікарський засіб антимікробної дї / К.С.Мусієнко. - Заявл.: 19.06.2014. Опубл.: 10.11.2014. - Бюл. №4.

5. Ццивунін В.В., Штриголь С.Ю., Прокопенко Ю.С. та ін. // Клінічна фармація. - 2012. - Т. 16, №4. - С. 47-50.

6. Цивунін В.В., Штриголь С.Ю., Прокопенко Ю.С. та ін. // УБФЖ. - 2014. - №3. - С. 45-49.

7. Юсіфова Д.Ю., Малоштан Л.М., Шаталова О.М. // УБФЖ. - 2014. - №6. - С. 47-50.

8. Сударікова Ю. Екзотичні дерева, кущі та ліани в ландшафтах України. - К.: Наш формат, 2011. - 336 с.

9. Bioecological justification assortment of shrubs for landscaping urban landscapes / A.Semenyutina, S.Kostyukov. Montreal, 2013. - 164 p.

10. Gupta R. // Pharmacognos. Res. - 2013. - №5. - C. 286-290.

11. Hosseinzadeh H., Ramezani M., Shafaei H. // J. of Acupuncture and Meridian Studies. - 2013. - №6. - P. 12-17.

12. Ion T. // Farmacia. - 2009. - №57. - P. 141-156.

13. Planting: A New Perspective / N.Kingsbury, P.Oudorf. - Portland: Timber Press, 2013. - 280 p.

14. Sandeep P. // Pharmacol. On. News. - 2009. - №2. - P. 586-595.

15. Underlying Mechanisms of Epilepsy // Croatia: InTech Publisher, 2011. - P. 269-282.

16. Weici T., Gerhard E. Chinese Drugs of Plant Origin: Chemistry, Pharmacology, and Use in Traditional and Modern Medicine. - London: Springer, 1992. - 1056 p.

17. Wakeel O.K., Umukoro S., Kolawole O.T. et al. // Asian J. of Biomed. and Pharmac. Sci. - 2014. - №4. - P. 44-47.

ПОРІВНЯЛЬНЕ ФІТОХІМІЧНЕ ТА ФАРМАКОЛОГІЧНЕ ВИВЧЕННЯ ЕКСТРАКТІВ ЛИСТЯ ЧАГАРНИКІВ ФЛОРИ УКРАЇНИ

Н.А.Близнюк, Ю.С.Прокопенко, В.А.Геореіяни, В.В.Цивунін

Ключові слова: фрітохімічний аналіз; фрармакологічний аналіз; фрлора України; чагарники; екстракт

У фрлорі України такі рослини, як Forsythia europaea Deg. et Bald, Jasminum officinale L., Berberis thunbergii DC, Weigela hybrida Jaeg., Ligustrum vulgare L. ma Corylus avellana L. посidaюmь особливе місце серед чагарників. Метою нашого дослідження було вивчення взаємозв'язку між хімічним складом та протисудомною активністю екстрактів з листя представлених рослин. У результаті проведеного аналізу було встановлено, що водні екстракти Forsythia europaea ma Corylus avellana характеризуються найбільшим вмістом фрлавоноїдів у порівнянні з іншими екстрактами, що аналізувались. Сухий спиртовий (96\%) екстракт Corylus avellana ma cyхий спиртовий (50\%) екстракт Jasminum officinale характеризувались найвищим вмістом поліфенолів (1,314\% та 1,301\%, відповідно). Найбільш вираженим протисудомним ефректом характеризувався сухий водний екстракт листя Corylus avellana. Сухі екстракти листя Berberis thunbergii, Weigela hybrida i Ligustrum vulgare не проявили значних протисудомних властивостей. Отримані результати дозволяють охарактеризувати сухий водний екстракт Corylus avellana як перспективну субстанцію для розробки оригінального фрітотерапевтичного засобу з протисудомною дією.

\section{СРАВНИТЕЛЬНОЕ ФИТОХИМИЧЕСКОЕ И ФАРМАКОЛОГИЧЕСКОЕ ИЗУЧЕНИЕ ЭКСТРАКТОВ ЛИСТЬЕВ КУСТАРНИКОВ ФЛОРЫ УКРАИНЫ Н.А.Близнюк, Ю.С.Прокопенко, В.А.Георгиянц, В.В.Цывунин}

Ключевые слова: фритохимический анализ; фрармакологический анализ; фрлора Украины; кустарники; экстракт

Во фрлоре Украины такие растения, как Forsythia europaea Deg. et Bald, Jasminum officinale L., Berberis thunbergii DC, Weigela hybrida Jaeg., Ligustrum vulgare L., u Corylus avellana L. занимают особое место среди кустарников. Целью нашего исследования было изучение взаимосвязи химического состава и противосудорожного действия экстрактов из листьев представленных растений. В результате проведенного анализа было обнаружено, что водные экстракты Forsythia europaea u Corylus avellana характеризуются наивысшим содержанием фрлавоноидов по сравнению с другими анализируемыми экстрактами. Сухой спиртовый (96\%) экстракт Corylus avellana и сухой спиртовый (50\%) экстракт Jasminum officinale характеризуются наивысшим содержанием полифенолов (1,31\% и 1,30\%, соответственно). Наиболее выраженным противосудорожным эфффектом характеризуется сухой водный экстракт листьев Corylus avellana. Сухие экстракты листьев Berberis thunbergii, Weigela hybrida u Ligustrum vulgare не проявили выраженных противосудорожных свойств. Полученные результаты позволяют охарактеризовать сухой водный экстракт Corylus avellana как перспективную субстанцию для разработки оригинального фритотерапевтического средства с противосудорожным действием. 